\section{VILNIUS TECH \\ Vilniaus Gedimino technikos universitetas \\ APLINKOS APSAUGOS INŽINERIJA / ENVIRONMENTAL PROTECTION ENGINEERING}

$2021 \mathrm{~m}$. kovo 19 d. Vilnius, Lietuva

19 March 2021, Vilnius, Lithuania
ISSN 2029-7157

eISSN 2029-7149

ISBN 978-609-476-270-3

eISBN 978-609-476-271-0

\title{
UTENOS RAJONO SAVIVALDYBĖS GYVENTOJŲ İPROČIŲ TVARKYTI DIDELIŲ GABARITŲ IR BUITYJE SUSIDARANČIAS PAVOJINGĄSIAS ATLIEKAS TYRIMAS
}

\author{
Inga Jakštoniené ${ }^{1}$, Ingrida Pliopaitė Bataitiené ${ }^{2}$, Nijolè Rukšteliené ${ }^{3}$ \\ Utenos kolegija, Verslo ir technologiju fakultetas \\ El.p.ringajakstoniene@gmail.com; ${ }^{2}$ ingrida.pl@gmail.com; ${ }^{3}$ rukstelienen@gmail.com
}

\begin{abstract}
Anotacija. Straipsnyje analizuojami Utenos rajono savivaldybès gyventojų apklausos, kuria siekiama išaiškinti respondentų ipročius tvarkyti didelių gabaritų ir buityje susidarančias pavojingąsias atliekas, rezultatai. Nustatyta, kad $95 \%$ respondentų mano, kad rūšiuojant atliekas saugoma gamta, mažèja atliekų tvarkymo išlaidos, ir tik maža dalis apklaustujų buvo skeptiški šiuo klausimu. Deja, realybejje tai įgyvendinti sekasi nelengvai, nes net $21 \%$ respondentų teigia niekada nesinaudojantys šia atliekų surinkimo paslauga, net trečdalis respondentų dalị pavojingụjų atliekų išmeta ị komunalinių atliekų konteinerius, o šeštadalis didelių gabaritų atliekas tiesiog palieka prie buitinių atliekų konteinerių. Nepaisant šių problemų, respondentai gerai vertina UAB ,Utenos komunalininkas“ ir kitų atliekų tvarkytojų darbą.
\end{abstract}

Reikšminiai žodžiai: Utenos rajonas, didelių gabaritų atliekos, pavojingosios atliekos, atliekų tvarkymas.

\section{Ivadas}

Atliekos yra problema, prie kurios atsiradimo prisidedame kiekvienas. Statistikos duomenimis, vienas ES gyventojas kasmet išmeta apie pusę tonos komunalinių atliekų (Oficialiosios statistikos portalas, 2019). Atliekos daro didžiulę ittaką aplinkai ir jos kokybei. Atliekų tvarkymo politika siekiama sumažinti atliekų žalą aplinkai ir visuomenès sveikatai bei padidinti Europos išteklių efektyvumą. Lietuvoje atliekų tvarkymo prioritetai, valstybinès atliekų tvarkymo užduotys, atliekų tvarkymo užduotys savivaldybėms yra apibrèžiamos Valstybiniame atliekų tvarkymo plane. Šis planas apima komunalines, gamybos ir kitos ūkinès veiklos atliekas, jų tvarkymo organizavimą ir tvarkymą Lietuvos Respublikos geografineje teritorijoje. Komunalinių, gamybos ir kitos ūkinès veiklos atliekų tvarkymo principu igyvendinimą valstybès lygmeniu reglamentuoja valstybinis atlieku tvarkymo planas, regiono lygmeniu - regioniniai atliekų tvarkymo planai, savivaldybių lygmeniu - savivaldybių atliekų tvarkymo planai ir savivaldybių atliekų tvarkymo taisyklès (Lietuvos Respublikos vyriausybè, 2002).

Tinkamas atliekų tvarkymas yra pagrindinis elementas, užtikrinantis resursų naudojimo efektyvumą ir tvarų
Europos ekonomikos augimą. Ilgalaikis šios politikos tikslas - paversti Europą perdirbančia visuomene, vengiančia atliekų susidarymo ir neišvengiamai susidarančias atliekas naudojančią kaip išteklius visur, kur įmanoma ir tokiu būdu minimizuoti gamtinių išteklių išgavimą. Atliekos privalo būti surinktos, išrǔšiuotos ir sutvarkytos, taip garantuojant ne tik išlaidų taupymą, šiltnamio dujų emisijų ir oro, žemès ir vandens taršos mažinimą.

Didelių gabaritų atliekos - tai seni baldai (kèdès, lovos, spintos, stalai, komodos ir kt.), langai, durys, dviračiai, kilimai, radiatoriai, automobilinės kèdutès, naudotos automobiliu padangos, vežimèliai, talpyklos ir kitos buityje susidarančios didelių matmenų atliekos (Aplinkos apsaugos agentūra, 2020).

Pavojingosios atliekos (PA) - atliekos, kurios pasižymi viena ar keliomis pavojingomis savybėmis, nurodytomis $2014 \mathrm{~m}$. gruodžio $18 \mathrm{~d}$. Komisijos reglamente (ES) Nr. 1357/2014 (Lietuvos Respublikos Seimas, 2021).

Buityje susidarančios didelių gabaritų atliekos, ịskaitant pavojingąsias atliekas, surenkamos apvažiuojant atliekų turètojus ir priimant šias atliekas didelių gabaritu atliekų surinkimo aikštelèse (Lietuvos Respublikos aplinkos ministerija, 2012). Šiuo metu Lietuvoje veikia 98

(C) 2021 Inga Jakštonienė, Ingrida Pliopaitė Bataitienė, Nijolė Rukštelienė. Leidėjas Vilniaus Gedimino technikos universitetas. Šis straipsnis yra atvirosios prieigos straipsnis, turintis Kūrybinių bendrijų (Creative Commons) licenciją (CC BY 4.0), kuri leidžia neribotą straipsnio ar jo dalių panaudą su privaloma sąlyga nurodyti autorių ir pirminị šaltinį. 
didelių gabaritu atliekų surinkimo (prièmimo) aikštelès. Šios aikštelès yra suskirstytos pagal apskritis: Alytaus, Kauno, Klaipėdos, Marijampolès, Panevėžio, Šiaulių, Tauragès, Telšių, Utenos ir Vilniaus (Aplinkos apsaugos agentūra, 2020).

Savivaldybių atliekų tvarkymo sistemos turi būti organizuotos taip, kad didesnès gyvenvietès ir miestai būtu aprūpinti buitinių pavojingų atliekų atskiro surinkimo priemonèmis (Lietuvos Respublikos aplinkos ministerija, 2018). Tačiau literatūros šaltinio (Valstybès kontrolè, 2018) duomenimis, savivaldybès nesurenka beveik pusès šių atliekų, pvz., 2014-2017 m. didelių gabaritų atliekų surinkimo aikštelèse ir apvažiavimo būdu buvo surinkta $10424 \mathrm{t}$ buityje susidariusių pavojingujjų atliekų, o $9473 \mathrm{t}$ pateko ị buitinių atliekų konteinerius kartu su kitomis atliekomis.

Lietuvoje kasmet susidaro vidutiniškai 163 tūkst. t pavojingujų atliekų (Valstybès kontrolè, 2018). Pavojingujų atliekų tvarkymo bendrovès „Toksika“ 2019 m. duomenimis, Lietuvos gyventojų buityje kasmet susikaupia daugiau kaip 20 tūkst. $\mathrm{t}$ sveikatai ir aplinkai žalingų atliekų. Vidutiniškai kasmet $0,8 \mathrm{~kg}$ pavojingujų atliekų sukaupia kiekvienas Lietuvos gyventojas. $2018 \mathrm{~m}$. duomenimis, apie $2600 \mathrm{t}$ buityje susidariusių pavojingujų atliekų vidutiniškai kasmet surenkama savivaldybių organizuojamose pavojingujų atliekų surinkimo sistemose, tačiau apie $2368 \mathrm{t}$ buityje susidariusių pavojingujų atlieku vidutiniškai kasmet patenka ị nepavojingų atliekų sąvartyną arba MBA ịrenginius (Valstybès kontrolè, 2018). Netinkamas tvarkymas ar netvarkymas gali sukelti pavojų žmogaus sveikatai, gyvybei ir padaryti žalos aplinkai. Šios atliekos neretai būna itin degios, todèl gali sukelti gaisrą, edžios atliekos gali lemti odos nudegimus ar pakenkti turtui, o lètinis sunkiujų metalų poveikis gali turèti neigiamų pasekmių žmonių sveikatai.

Tyrimo tikslas - ištirti Utenos rajono savivaldybès gyventojų ịpročius tvarkyti didelių gabaritų ir buityje susidarančias pavojingąsias atliekas.

\section{Metodika}

Utenos rajono savivaldybės gyventojų požiūrio ị didelių gabaritų ir buityje susidarančių pavojingụjų atliekų tvarkymą tyrimui buvo naudotas pirminis duomenų rinkimo metodas - sudarytas klausimynas, vadovaujantis tokiais kriterijais (Kardelis, 2002):

- apklausos gavejas turi prisistatyti;

- įžangoje turi būti apibūdinta problema, tikslas;
- $\quad$ klausimai suformuluoti nereiškiant savo nuomonès;

- atsakymai vertinami nerodant savo pritarimo ar nepritarimo.

Gauti klausimyno atsakymų duomenys gali būti grupuojami pagal (Kardelis, 2002):

1) nominaliąą skalę - objektyvių duomenų apie respondentus nustatymas, jis sudaro demografinę anketos dalį;

2) ranginę skalę - kai atsakymai grupuojami pagal didèjančią ar mažejjančią tvarką;

3) intervalinę skalę - padeda išmatuoti ir ịvertinti požymius.

Lietuvos Statistikos departamento duomenimis, $2019 \mathrm{~m}$. liepos $1 \mathrm{~d}$. Utenos rajono savivaldybeje gyveno 37427 gyventojai, vidutinis namų ūkis $2018 \mathrm{~m}$. buvo 2,18 asmens. Atsižvelgiant ị šią informaciją, daroma prielaida, kad Utenos rajono savivaldybeje yra apie 17100 namų ūkių. Apklausoje dalyvavo gyventojai, gyvenantys Utenos mieste ir Antalgès kaime, Vyžuonų, Tauragnų miesteliuose. Atliekų tvarkymas - visuomeninè problema, todèl tyrimo imtis buvo analizuota kaip generalinè visuma namų ūkių skaičius. Pasirinktas Kardelio (Kardelis, 2007) siūlomas būdas - pritaikyti Paniotto formulę. Reikiamas apklausos dalyvių skaičius - imties tūris - nustatytas pagal šią formulę (Kardelis, 2007):

$$
n=\frac{1}{\Delta^{2}+\frac{1}{N}},
$$

čia $n$-imties dydis (reikiamas apklausti Utenos savivaldybès gyventojų skaičius); $\Delta$ - leidžiamas paklaidos dydis (socialinių mokslų tyrimuose standartine paklaida laikoma $5 \%$, kurią gauname su 0,95 tikimybe); $N$ - tiriamos visumos dydis.

Apklausos imties tūris - 376 namų ūkių atstovų nuomonè. Gauti klausimyno rezultatai analizuoti vadovaujantis matematinès statistikos pagrindais.

\section{Rezultatai ir jų analizè}

Atliekant tyrimą respondentai buvo suskirstyti i grupes pagal:

- amžių. Didžioji dalis, t. y. 39,2\%, respondentų priklausè grupei 31-50 m., 51-65 m. amžiaus grupè sudarè $33,5 \%, 16,5 \%$ sudarè daugiau nei 65 m., o 18-30 m. amžiaus apklaustųų buvo $10,8 \%$; 
- išsilavinimą, kuris yra svarbus veiksnys, lemiantis aplinkosauginį atsakingumą ir suvokimą. Didžioji dalis respondentų (47\%) turi aukštaji universitetini, $16 \%$ - vidurinį, aukštaji neuniversitetini išsilavinimą turi $27 \%$ respondentu, $8 \%$ - profesinị ir $2 \%$ - pagrindinị išsilavinimą; - socialinę padètị. Pagal užimtumą respondentai pasiskirstę taip: $61 \%$ - samdomi darbuotojai, $19 \%$ - senjorai, $2 \%$ - studentai / moksleiviai, niekur nedirbantys $-13 \%$, kita dalis respondentų, tokių kaip verslininkai, dirbantys studentai, ūkininkai, valstybès tarnautojai;

- gyvenamąsias vietas. $49 \%$ respondentų gyvena mieste (35\% butuose ir $14 \%$ individualiuose namuose), $51 \%$ kaime, iš jų $2 \%$ Utenos rajono kolektyviniame sode.

Respondentų požiūris ị atliekų rūšiavimą atspindimas 1 paveiksle.

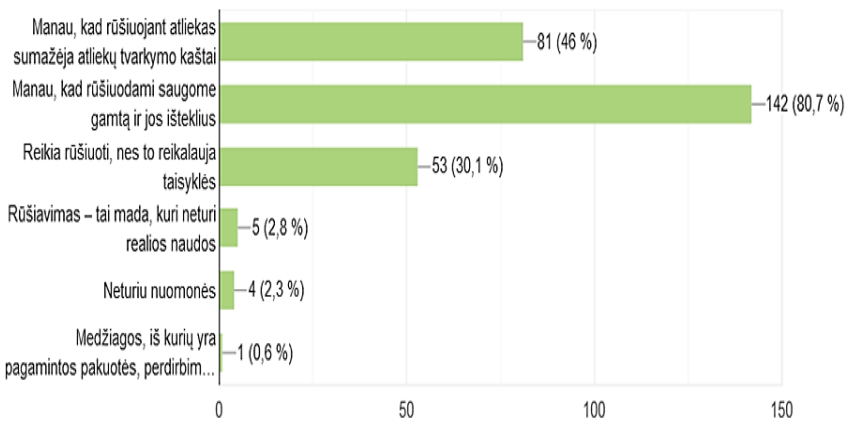

1 paveikslas. Respondentų požiūris ị atliekų rūšiavimą

Didžioji dalis $(81 \%)$ apklaustujų mano, kad rūšiuodami saugome gamtą ir aplinką, ir tik $3 \%$ mano, kad rūšiavimas - tai mada, kuri neturi realios naudos, o $2 \%$ neturi nuomonès.

Didžioji dalis respondentų (69\%) kaip pavojingąsias atliekas (PA), susidarančias buityje, ịvardijo buitinès chemijos produktus, $46 \%$ - elektros ir elektroninès irangos atliekas, $43 \%$ - pasenusius vaistus ir termometrus, $40 \%$ - galvaninius elementus ir akumuliatorius, $29 \%-$ lako, dažų, skiediklių atliekos, $28 \%$ - naudotus tepalus, tepalų filtrus, tepaluotus skudurus ir kitas naftos produktų atliekas.

Tyrimo metu paaiškejo, kad didžioji dalis respondentų (72\%) prie didelių gabaritų atliekų priskiria baldų atliekas, $47 \%$ - naudotas padangas, $30 \%$ - didelių matmenu pakuotes, $22 \%$ apklaustųjų nurodè susidarančias kilimų atliekas, $7 \%$-dviračius ir tik $1 \%$ respondentų teigia, kad visai nesudaro atliekų. Ivardydami susidarančius kiekius respondentai nurodè: $45 \%$ apklausos dalyvių nurodè, kad jiems kas 2-3 metus susidaro nedideli kiekiai atliekų: $40 \%$-iki $2 \mathrm{~m}^{3}, 14 \%$ - iki $10 \mathrm{~m}^{3}$, ir $2 \%$ daugiau nei $10 \mathrm{~m}^{3}$.

$39 \%$ respondentų nurodè, kad naudojasi didelių gabaritų ir buityje susidarančiu pavojingujjų atliekų surinkimo paslauga, kad kartais naudojasi surinkimo paslauga, nurode $40 \%$, o niekada nesinaudoja $21 \%$. Vertindami stambiagabaričių atliekų tvarkymo sistemą Utenos rajono savivaldybeje, paslaugos kokybę, motyvuodami patogumu, surinkimo grafikų aiškumu, gerai ịvertino $43 \%$ respondentų, $27 \%$ respondentu paslaugą įvertino gerai, nes galima patiems pristatyti ị didelių gabaritų atliekas ị surinkimo aikšteles patogiu metu, 15 \% paslaugą įvertino vidutiniškai, nes sunku išnešti atliekas prie gatvès, $9 \%$ respondentų paslaugą ịvertino blogai, nes retai vežama, ne visur privažiuojama, $1 \%$ nurode, kad nesinaudoja arba kol kas nesinaudoja šiomis paslaugomis, ir tik $0,6 \%$ pageidavo surinkti atliekas kartą per ketvirti. Apibendrinant atliekų tvarkymo sistemos darbą matyti, kad net $70 \%$ respondentu gerai ir $15 \%$ patenkinamai vertina stambiu gabaritų atliekų tvarkymo sistemą, t. y. geriau negu buityje susidarančių pavojingujų atliekų tvarkymo sistemą (57\% ir atitinkamai $29 \%$ ).

2 paveiksle pateikiami duomenys apie tai, kaip respondentai linkę tvarkyti didelių gabaritų atliekas.

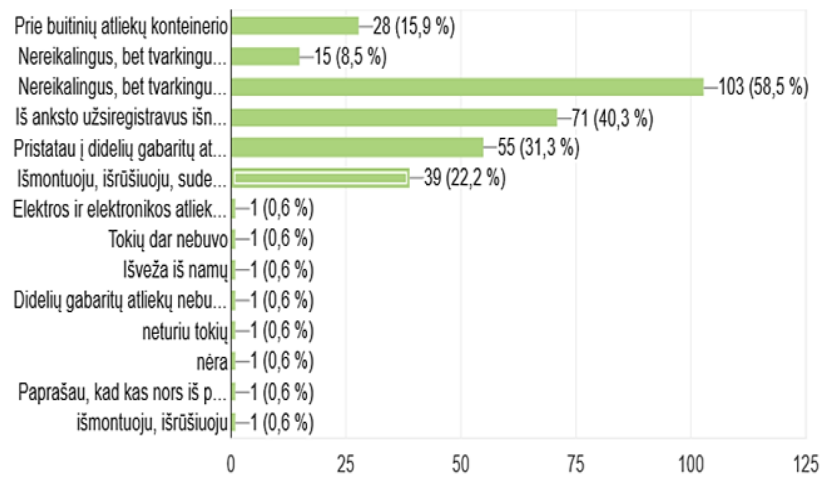

2 paveikslas. Kur respondentai deda didelių gabaritų atliekas?

$59 \%$ apklaustujjų nereikalingus, bet tvarkingus ir tinkamus naudoti daiktus stengiasi atiduoti, $40 \%$ is anksto užsiregistravę išneša prie kelio, kad jas surinktu apvažiavimo būdu pagal grafiką, $31 \%$ pristato ị didelių gabaritų atliekų aikšteles, 22 \% išmontuoja, išrūšiuoja, sudegina medieną, tekstilę, atskiria metalą, likučius išmeta i buitinių atlieku konteineri, $16 \%$ respondentų 
nurodé, kad didelių gabaritu atliekas vis dèlto palieka prie buitinių atliekų konteinerio ir $9 \%$ nereikalingus, bet tvarkingus ir tinkamus naudoti daiktus nuveža ị daiktu dalijimosi stotelę „Dalinkimės“. Beveik $1 \%$ apklaustujų teigè, kad neturi jokių susidarančių atliekų. Taigi šie rezultatai leidžia manyti, kad gyventojai ị vartojimą žiūri vis atsakingiau. Atiduodami daiktus, žmonès ne tik prisideda prie žiedinès ekonomikos, bet ir suteikia laimès tiems, kuriems tų daiktų reikia labiausiai.

3 paveiksle pateikiami duomenys apie tai, kaip respondentai linkę tvarkyti pavojingąsias atliekas.

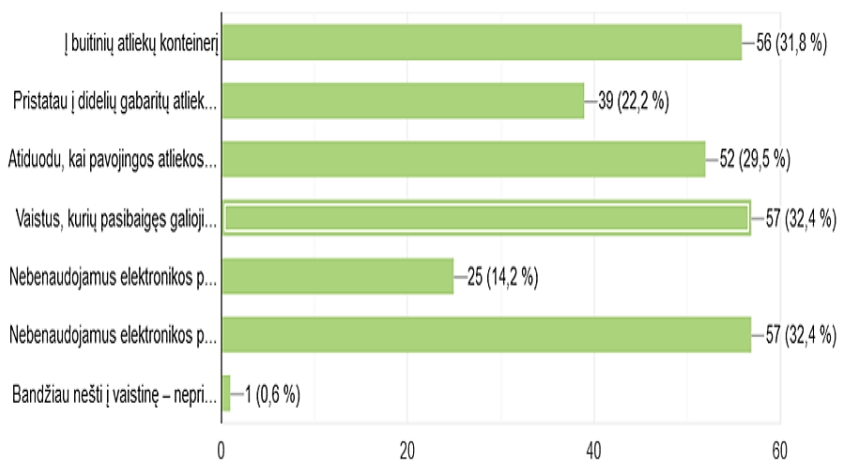

3 paveikslas. Kur respondentai deda buityje susidarančias pavojingąsias atliekas?

$31,8 \%$ respondentų buityje susidarančias PA išmeta i buitinių atliekų konteinerị, 32,4\% apklaustujų vaistus, kurių pasibaigęs galiojimas, neša ị vaistinę, taip pat 32,4 \% nebenaudojamus elektronikos prietaisus pristato elektros ir elektronikos atliekas tvarkančioms įmonèms, $30 \%$ nurodè, kad pavojingąsias atliekas atiduoda surinkèjams, vykstantiems apvažiavimo būdu. Savarankiškai atliekas pristatančių ị didelių gabaritų atliekų surinkimo aikštelę dalis sudaro $22 \%$ ir tik $1 \%$ apklaustujų teigia, kad vaistus, kurių pasibaigęs galiojimas, nešè ị vaistinę, tačiau tokia paslauga nebuvo suteikta.

Analizuojant PA susidarymo kiekius šiek tiek daugiau nei pusè apklaustujų (53\%) nurodé, kad jų susidaro $1 \mathrm{~kg}, 28 \%$ - iki $5 \mathrm{~kg}, 14 \%$ - iki $20 \mathrm{~kg}, 5 \%$ - iki $50 \mathrm{~kg}$. Lyginant su šaltinyje (Valstybès kontrolè, 2018) pateikiamais duomenimis (vidutiniškai kasmet $0,8 \mathrm{~kg}$ pavojingujų atliekų sukaupia kiekvienas Lietuvos gyventojas), galima daryti išvadą, kad pusės respondentų nurodytas susidarančių PA kiekis buityje yra artimas Lietuvos vidurkiui. Tačiau likusios dalies respondentų nurodytas susidarančiu buityje PA kiekis yra gerokai didesnis už vidutinį Lietuvos rodiklį. Tai galèjo lemti šios priežastys: netinkamas atliekų priskyrimas pavojingosioms atliekoms arba nepakankamas žinių lygis apie atliekų klasifikavimą.

Vertinant buityje susidarančiu PA tvarkymo sistemą Utenos mieste ir rajone, $31 \%$ respondentų nurodè, kad paslauga patogi, aiškūs surinkimo grafikai, $26 \%$ paslaugą ivertino gerai motyvuodami, kad galima patiems pristatyti ị didelių gabaritų atliekų surinkimo aikšteles patogiu metu. $29 \%$ respondentų paslaugą įvertino vidutiniškai, nes pavojingąsias atliekas sudètinga išrūšiuoti, neaktuali paslauga dèl mažo atliekų kiekio, $9 \%$ respondentų paslaugą ìvertino blogai ir nurodè, kad retai vežama, ne visur privažiuojama, nepriimamos skystosios atliekos ir tik 0,6 \% nurode kitas priežastis. Pagal apklausos rezultatus galima teigti, kad visuomenè teigiamai vertina buityje susidarančių PA tvarkymo sistemą Utenos mieste ir rajone.

Norint ịvertinti požiūrio ị didelių gabaritų ir buityje susidarančių pavojingujų atliekų tvarkymą skirtumą tarp miesto ir kaimo gyventojų, atliekama apklausos duomenu analizè, lyginant miesto ir kaimo gyventojų atsakymus.

4 paveiksle pateikiamas respondentų amžiaus pasiskirstymas atsižvelgiant i gyvenamają vietą - kaimo ar miesto teritoriją.

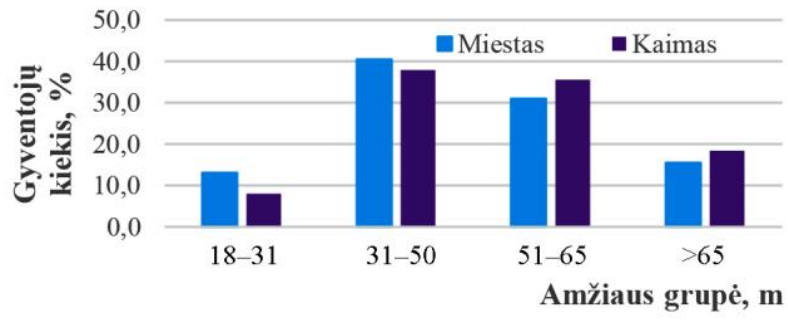

4 paveikslas. Respondentų amžiaus pasiskirstymas, atsižvelgiant ị gyvenamają vietą

Analizuojant kaimo ir miesto respondentų pasiskirstymą pagal amžiaus grupes, galima pastebeti, kad tiek miesto, tiek kaimo teritorijoje gyvenančių respondentų pagrindinès amžiaus grupès yra nuo 31-50 ir 51-65 metu amžiaus grupès. Tai sudaro $71,4 \%$ (miesto teritorija - M) ir 73,6\% (kaimo teritorija - K). Atsižvelgiant i ị šiuos duomenis, norint išryškinti panašumus ir skirtumus tarp miesto ir kaimo gyventojų požiūrio ị didelių gabaritu ir buityje susidarančių pavojingujjų atliekų tvarkymą, analizuojami šiu amžiaus grupių atsakymai. 
Inga Jakštonienè , Ingrida Pliopaitè Bataitienè , Nijolė Rukštelienè. Utenos miesto ir rajono gyventojų požiūrio ị dideliụ gabaritų ir buityje susidarančių pavojingų atliekų tvarkymą tyrimas

1 lentelè. Pagrindinès dalies respondentų pasiskirstymas (\%) pagal turimą išsilavinimą

\begin{tabular}{|c|c|c|c|c|}
\hline \multirow{2}{*}{ Išsilavinimas } & \multicolumn{2}{|c|}{$31-50$ metų } & \multicolumn{2}{|c|}{$51-65$ metų } \\
\hline & Miestas & Kaimas & Miestas & Kaimas \\
\hline Pagrindinis & 2,9 & 0 & 0 & 2,6 \\
\hline Profesinis & 5,9 & 20,0 & 0 & 2,6 \\
\hline Vidurinis & 2,9 & 17,1 & 0 & 2,6 \\
\hline Aukštasis neuniversitetinis & 32,4 & 17,1 & 23,1 & 17,9 \\
\hline Aukštasis universitetinis & 55,9 & 40,0 & 76,9 & 53,8 \\
\hline
\end{tabular}

1 lentelèje pateikiamas pagrindinès dalies respondentų pasiskirstymas pagal turimą miesto ir kaimo gyventojų išsilavinimą. Didžioji dalis respondentų, tiek miesto, tiek kaimo gyventojų, turi aukštaji išsilavinimą - 31-50 metų grupejje jų yra 88,2\% (M) ir 57,1\% (K); 51-65 metu grupèje 100,0\% (M) ir 71,8\% (K). Tačiau tarp mieto gyventojų visgi yra didesnis skaičius respondentų, turinčiu aukštaji (universitetinị ar neuniversitetini išsilavinimą) nei kaimo gyventojai. Tarp kaimo gyventojų didesnis skaičius yra igiję profesini arba tik vidurinị išsilavinimą.

Didžioji dalis respondentų yra samdomi darbuotojai $86,7 \%(\mathrm{M})$ ir $78,5 \%(\mathrm{~K})$ ir tik nedidelè dalis, vykdant apklausą, buvo nedirbantys $-10,0 \%(\mathrm{M})$ ir $16,9 \%(\mathrm{~K})$. Tačiau apklausos vykdymo metu nedirbančių respondentu buvo daugiau kaimo vietoveje.
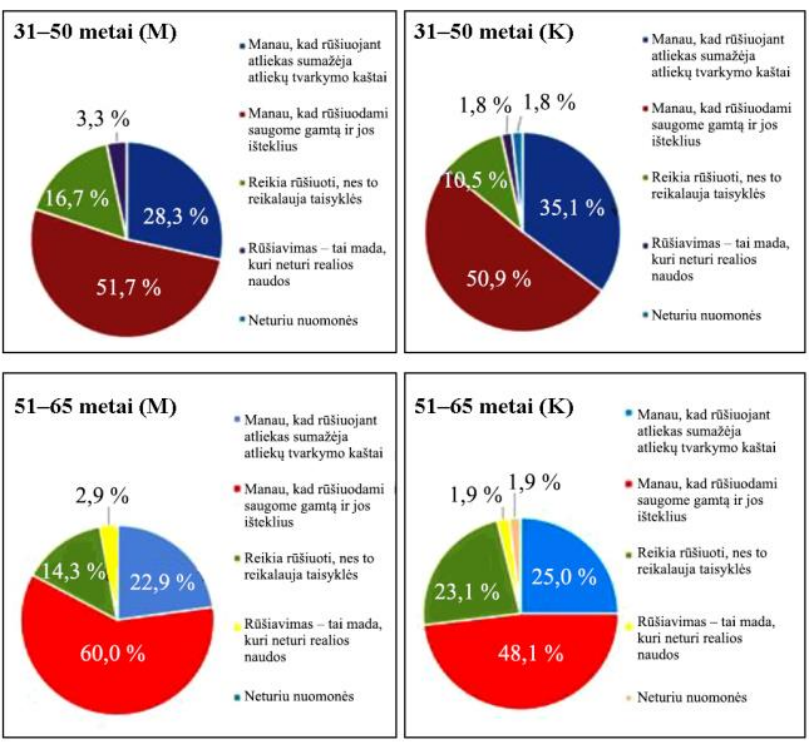

5 paveikslas. Pagrindinės respondentų dalies požiūris ị atliekų rūšiavimą
5 paveiksle pateikiami duomenys, kurie atspindi miesto ir kaimo gyventojų požiūrị ị atliekų rūšiavimą. Analizuojant miesto ir kaimo gyventojų požiūrị i atliekų rūšiavimą, galima teigti, kad miestiečius motyvuoja rūšiuoti tai, kad jie mano, jog rūšiuodami saugo gamtą ir jos išteklius, be to, rūšiuojant atliekas sumažejja atliekų tvarkymo išlaidos. Tik nedidelè dalis miesto gyventojų (vidutiniškai 15,5 \%) rūšiuoja atliekas, nes to reikalauja taisyklès. Kaimo gyventojai rǔšiuoja dèl tụ pačių priežasčių kaip ir miesto gyventojai, tačiau didesnè dalis kaimo gyventojų teikia svarbą atliekų rūšiavimo taisyklių reikalavimams - vidutiniškai 16,8 \%. Visgi tarp respondentų yra ir tokių, kurie mano, jog atliekų rūšiavimas - tai mada, kuri neturi realios naudos.

6 paveiksle pateikiami duomenys apie respondentu (M ir K) buityje dažniausiai susidarančias pavojingąsias atliekas.

a)

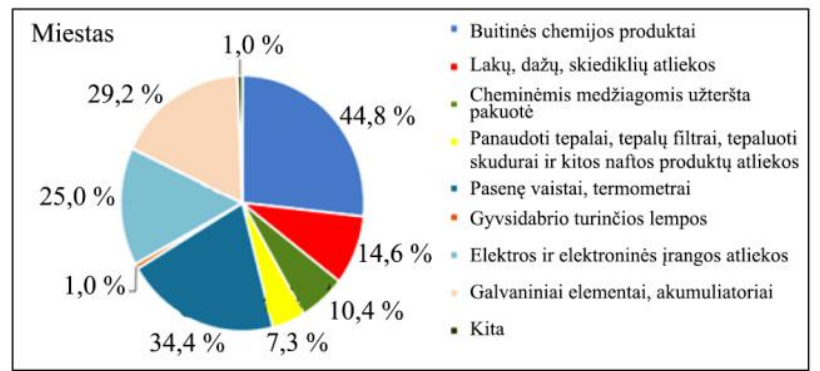

b)

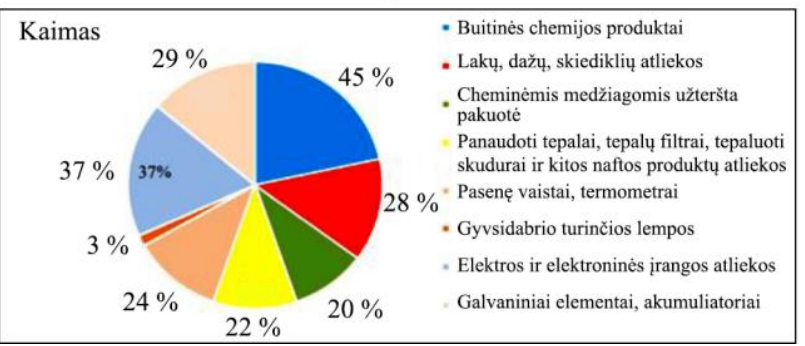

6 paveikslas. Respondentų $(\mathrm{a}-\mathrm{M}, \mathrm{b}-\mathrm{K})$ buityje dažniausiai susidarančios PA 
Miesto gyventojai įvardija, kad dažniausiai buityje susidaro šių atliekų: buitinès chemijos produktai ( $44,8 \%)$, pasenę vaistai, termometrai $(34,4 \%)$, elektros ir elektroninès irangos atliekos $(25,0 \%)$ ir galvaniniai elementai, akumuliatoriai $(29,2 \%)$. Kaimo gyventojų buityje buitinès chemijos produktų ir galvaninių elementų, akumuliatorių susidaro beveik tiek pat, kaip ir miestiečio buityje - atitinkamai $45,0 \%$ ir $29,0 \%$; pasenusiu vaistų, termometru - net 10,4 \% mažiau; elektros ir elektroninès ịrangos atliekų - net $12 \%$ daugiau. Be to, kaimo gyventojų buityje susidaro nemažai ir lako, dažų, skiediklių atliekų ( $28 \%)$, cheminėmis medžiagomis užterštų pakuočių ( $20 \%$ ), naudotų tepalų, tepalų filtrų, tepaluotų skudurų ir kitų naftos produktų atliekų $(22 \%)$. Ši skirtumą galima sieti su skirtingu miestiečio ir kaimiečio gyvenimo būdu bei veikla.

7 paveiksle pateikiami duomenys apie dideliu gabaritų atliekų susidarymą respondentų buityje.

a)

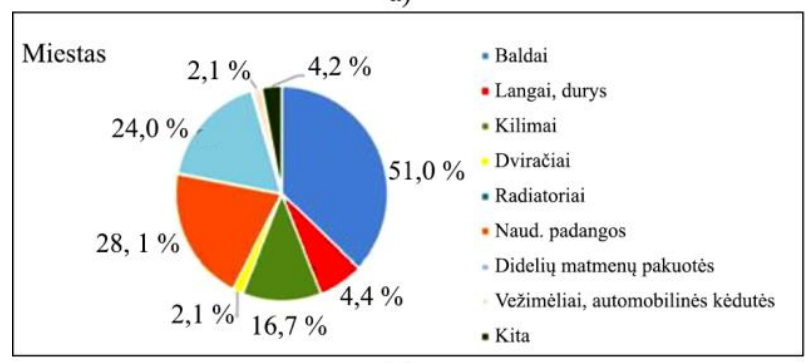

b)

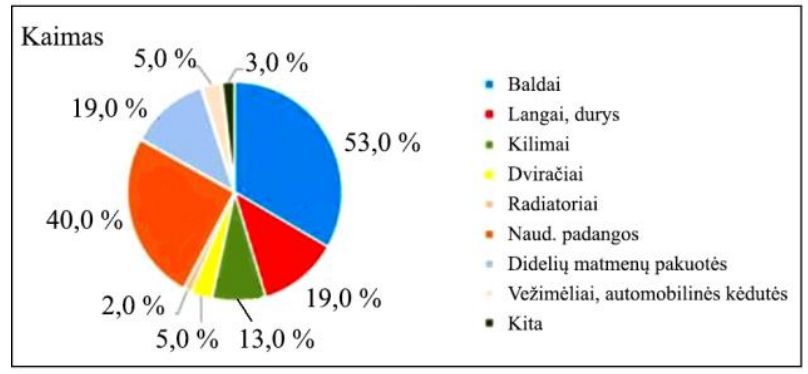

7 paveikslas. Duomenys apie didelių gabaritų atliekų susidarymą respondentų $(\mathrm{a}-\mathrm{M}, \mathrm{b}-\mathrm{K})$ buityje

Didžiausią dali tiek miestiečiu, tiek kaimo gyventojų buityje susidarančių didelių gabaritų atliekų sudaro baldai atitinkamai 51,0 (M) \% ir 53,0 \% (K). Taip pat nemažai susidaro ir naudotų padangų $(28,1(\mathrm{M}) \%$ ir $40,0 \%(\mathrm{~K}))$ bei didelių matmenų pakuočių (24,0 (M) \% ir 19,0\% (K)). Didesnis naudotų padangų skaičius kaimo gyventojų buityje gali būti sietinas su žmogaus ūkine veikla.

8 paveiksle pateikiami duomenys apie miesto ir kaimo gyventojų dideliu gabaritų ir buityje susidarančiu pavojingụjų atliekų surinkimo paslaugos naudojimą.

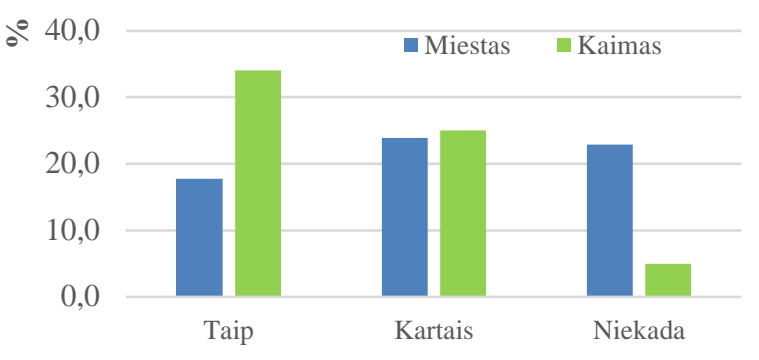

8 paveikslas. Duomenys apie didelių gabaritų ir buityje susidarančių PA surinkimo paslaugos naudojimą

Iš 8 paveiksle pateiktų duomenų matyti, kad kaimo gyventojai $(34,0 \%)$ didelių gabaritu ir buityje susidarančių pavojingujjų atliekų surinkimo paslaugą naudoja dažniau nei miesto gyventojai $(17,7 \%)$ ir net $22 \%$ miesto gyventojų nèra naudojęsi šia paslauga.

Didžioji miesto ir kaimo gyventojų dalis nereikalingus, bet tvarkingus ir tinkamus naudoti daiktus stengiasi kam nors atiduoti, tačiau dalijimosi stotele „Dalinkimès“ nèra populiari nei tarp miesto, nei tarp kaimo gyventojų ši tvarkymo būdą renkasi 3,1 \% (M) ir 8,0 \% (K) respondentų. Kaimo vietovių gyventojai mielai renkasi didelių gabaritų atliekas tvarkyti iš anksto užsiregistravus išnešti prie kelio, kad jas surinktų apvažiavimo būdu pagal grafiką - net $46 \%$. Miesto gyventojai tokị didelių gabaritų atliekų tvarkymo būdą renkasi ne taip aktyviai - tik 13,5\%. Miesto gyventojai teikia prioritetą didelių gabaritų atlieku pristatymui ị didelių gabaritų atliekų aikšteles $-33,3 \%$, o kaimo gyventojams ši paslauga nèra tokia patraukli - renkasi tik 12,0 \%. Išmontuoti, išrūšiuoti, sudeginti medieną, tekstilę, atskirti metalą, o likučius išmesti ị buitinių atlieku konteinerị linkę panašiai tiek miesto $(13,5 \%)$, tiek kaimo gyventojai $(17,0 \%)$ (9 paveikslas).

10 paveiksle pateikiama informacija apie pavojingujjų atliekų tvarkymo pasirinkimus miesto ir kaimo gyventojų. Didelè buityje susidarančių pavojingųjų atliekų dalis nukeliauja ị buitiniu atliekų konteinerius $-15,6 \%$ (M) ir 26,0 \% (K). Tai gali sukelti ekologinių problemų tolesniuose buitinių atliekų tvarkymo etapuose. Taip pat pastebima, kad kaimo gyventojai aktyviau taiko šių atliekų būdą, kai jos surenkamos apvažiavimo būdu $-28,0 \%$. I didelių gabaritų aikšteles pavojingąsias atliekas labiau linkę pristatyti miesto gyventojai $(19,8 \%)$ nei kaimo $(9,0 \%)$.

2 lentelëje pateikiami duomenys apie pavojingujų ir stambiagabaričių atliekų susidarymo kiekius miesto ir kaimo vietovèse. 


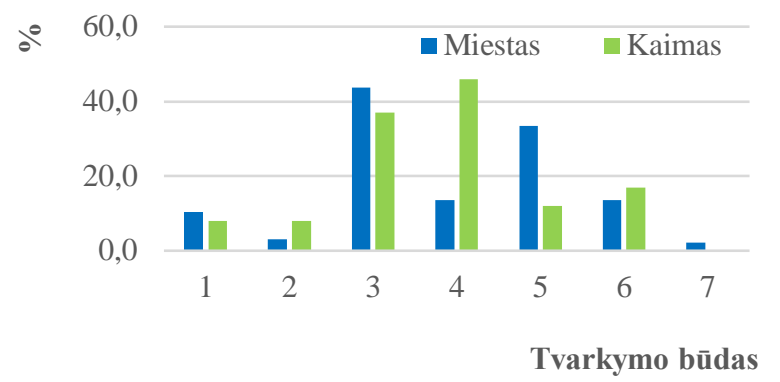

9 paveikslas. Didelių gabaritų atliekų tvarkymo būdai kaimo ir miesto vietovèse: 1 - prie buitinių atliekų konteinerio; 2 - nereikalingus, bet tvarkingus ir tinkamus naudoti daiktus nuvežu ị daiktų dalijimosi stotelę „Dalinkimès“;

3 - nereikalingus, bet tvarkingus ir tinkamus naudoti daiktus stengiuosi kam nors atiduoti; 4 -iš anksto užsiregistravęs išnešu prie kelio, kad jas surinktų apvažiavimo būdu pagal grafiką; 5 - pristatau ị didelių gabaritų atliekų aikšteles; 6 - išmontuoju, išrūšiuoju, sudeginu medieną, tekstilę, atskiriu metalą, likučius išmetu ị buitinių atliekų konteinerị; 7 - kita

Didžioji dalis miesto gyventojų linkę manyti, kad pavojingujų atliekų buityje susidaro iki $1 \mathrm{~kg} /$ metus. Kaimo gyventojai linkę manyti, kad pavojingujų atliekų buityje susidaro iki $5 \mathrm{~kg} /$ metus. Miesto gyventojų nurodomas PA susidarymo kiekis artimas vidutiniam Lietuvos rodikliui ( $0,8 \mathrm{~kg} / \mathrm{žm}$.), o kaimiškujų vietovių gyventojai nurodo net iki $6,25 \mathrm{k}$. didesnį dydị.

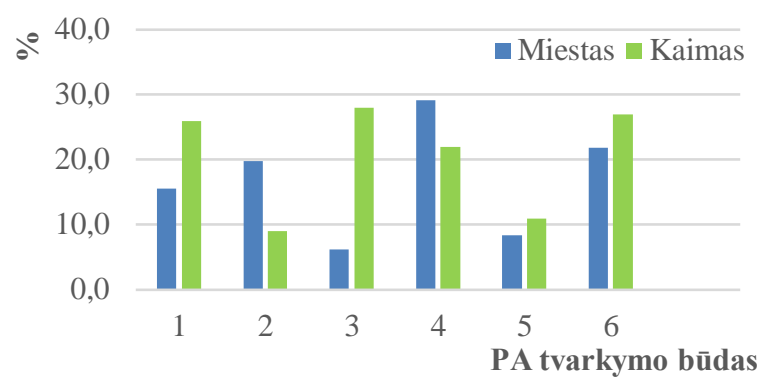

10 paveikslas. Pavojingųjų atliekų tvarkymo būdai kaimo ir miesto vietovėse: 1 - i buitinių atliekų konteinerị; 2 - pristatau i dideliu gabaritų atliekų surinkimo aikštelę pats; 3 - atiduodu, kai pavojingosios atliekos surenkamos apvažiavimo būdu; 4 - vaistus, kurių pasibaigęs galiojimas, nešu ị vaistinę; 5 - nebenaudojamus elektronikos prietaisus priduodu nemokamai paskambinęs elektros ir elektronikos atliekas tvarkančioms įmonèms; 6 - nebenaudojamus elektronikos prietaisus pristatau elektros ir elektronikos atliekas tvarkančioms įmonėms; 7 - kita

Didžioji dalis miesto respondentų mano, kad didelių gabaritu atlieku susidaro nedideli kiekiai kas 2-3 metus $(55,6 \%)$. Nors šiai minčiai pritaria $35,4 \%$ kaimo respondentų, didesnè jų dalis (41,5\%) mano, kad didelių gabaritų atliekų susidaro iki $2 \mathrm{~m}^{3}$.

Respondentų nuomoné apie pavojingųjų ir stambiagabaričių atliekų tvarkymą Utenos rajono savivaldybejje pateikiama 3 lenteleje.

2 lentelè. Pavojingųjų ir didelių gabaritų atliekų susidarantys kiekiai buityje

\begin{tabular}{|l|l|l|l|l|l|}
\hline \multicolumn{3}{|c|}{ PA buityje } & \multicolumn{3}{c|}{ Didelių gabaritų atliekos buityje } \\
\hline Kiekis & $\begin{array}{c}\text { M, respondentu } \\
\text { pasirinkimas \% }\end{array}$ & $\begin{array}{c}\text { K, respondentuc } \\
\text { pasirinkimas \% }\end{array}$ & \multicolumn{1}{|c|}{ Kiekis } & $\begin{array}{c}\text { M, respondentuc } \\
\text { pasirinkimas \% }\end{array}$ & $\begin{array}{c}\text { K, respondentų } \\
\text { pasirinkimas \% }\end{array}$ \\
\hline Iki $1 \mathrm{~kg}$ & 38,5 & 23,0 & Iki $2 \mathrm{~m}^{3}$ & 33,3 & 41,5 \\
\hline Iki $5 \mathrm{~kg}$ & 14,6 & 29,0 & Iki $10 \mathrm{~m}^{3}$ & 11,1 & 21,5 \\
\hline Iki $20 \mathrm{~kg}$ & 7,3 & 10,0 & Daugiau nei $10 \mathrm{~m}^{3}$ & 0,0 & 1,5 \\
\hline Iki $50 \mathrm{~kg}$ & 4,2 & 3,0 & Nedideli kiekiai kas 2-3 m & 55,6 & 35,4 \\
\hline
\end{tabular}

Pastaba: $\mathrm{M}$ - miestas; $\mathrm{K}$ - kaimas.

3 lentelè. Nuomonė apie pavojingujjų ir didelių gabaritų atliekų tvarkymą Utenos rajono savivaldybejje

\begin{tabular}{|l|l|l|l|l|l|l|}
\hline Nuomonė (PA) & $\mathrm{M}, \%$ & $\mathrm{~K}, \%$ & Nuomonè (Didelių gabaritų atliekos) & $\mathrm{M}, \%$ & $\mathrm{~K}, \%$ \\
\hline Gerai, patogu, aiškūs surinkimo grafikai & 12,7 & 45,5 & $\begin{array}{l}\text { Gerai, nemokama, patogu, aiškūs } \\
\text { surinkimo grafikai }\end{array}$ & 30,6 & 58,5 \\
\hline $\begin{array}{l}\text { Gerai, galima pristatyti patiems ị didelių } \\
\text { gabaritų atliekų surinkimo aikšteles patogiu } \\
\text { metu }\end{array}$ & 34,9 & 22,7 & $\begin{array}{l}\text { Gerai, galima pristatyti patiems ị didelių } \\
\text { gabaritų atliekų surinkimo aikšteles patogiu } \\
\text { metu }\end{array}$ & 37,1 & 18,5 \\
\hline $\begin{array}{l}\text { Vidutiniškai, sudètinga jas išrǔšiuoti, } \\
\text { neaktuali paslauga dėl mažo atliekų kiekio }\end{array}$ & 38,1 & 22,7 & $\begin{array}{l}\text { Vidutiniškai, sunku išnešti atliekas prie } \\
\text { gatvės }\end{array}$ & 14,5 & 12,3 \\
\hline $\begin{array}{l}\text { Blogai, retai vežama, ne visur privažiuo- } \\
\text { jama, nepriimamos skystosios atliekos }\end{array}$ & 7,9 & 7,6 & $\begin{array}{l}\text { Blogai, retai vežama, ne visur } \\
\text { privažiuojama }\end{array}$ & 12,9 & 9,2 \\
\hline Kita & 6,3 & 1,5 & Kita & 4,8 & 1,5 \\
\hline
\end{tabular}

Pastaba: $\mathrm{M}$ - miesto respondentų pasirinkimas; $\mathrm{K}$ - kaimo respondentų pasirinkimas. 
45,5\% kaime gyvenančių respondentų mano, kad PA tvarkymas yra geras, patogus, su aiškiais surinkimo grafikais. 38,1 \% mieste gyvenančių respondentų PA tvarkymą vertina vidutiniškai, mano, kad sudètinga atliekas išrūšiuoti, o teikiama paslauga neaktuali dèl mažo susidarančio pavojingujų atliekų kiekio. Šiai nuomonei pritartų 22,7 \% kaime gyvenančių respondentų. $34,9 \%$ miesto ir $22,7 \%$ kaimo respondentų mano, kad pavojingųjų atliekų tvarkymas Utenos mieste ir kaimuose yra geras, galima pavojingąsias atliekas pristatyti patiems ị didelių gabaritų atliekų surinkimo aikšteles patogiu metu. Apibendrinant galima teigti, kad didžioji dalis tiek miesto, tiek kaimo gyventojų pavojingujų atliekų tvarkymą Utenos rajono savivaldybejje vertina gerai arba vidutiniškai.

Respondentų požiūris ì didelių gabaritų atliekų tvarkymą Utenos mieste ir kaimuose skiriasi. 58,5\% kaime gyvenančių respondentų mano, kad šių atliekų tvarkymas yra geras, nemokamas, patogus, o atliekų surinkimo grafikai yra aiškūs. Šiai nuomonei pritartų $30,6 \%$ mieste gyvenančių respondentų. Visgi jų dauguma $(37,1 \%)$ šių atliekų tvarkymą vertina kaip gerą, galima pristatyti patiems ir atvežti atliekas į didelių gabaritų atliekų surinkimo aikšteles patogiu metu. Tokiai nuomonei pritartų 18,5 $5 \%$ kaime gyvenančių respondentų. Apibendrinant galima teigti, kad didžioji dalis tiek miesto, tiek kaimo gyventojų didelių gabaritų atliekų tvarkymą savivaldybeje vertina gerai, t. y. palankiau nei pavojingųjų atliekų tvarkymą.

Pastebima, kad stambių gabaritų atliekų nuolat dideja. 75,4\% (M) ir 61,5\% (K) respondentų mano, kad tai yra natūrali gerèjančio gyvenimo pasekmè, o šių atliekų tvarkymui reikia skirti daugiau pajègų.

\section{Išvados}

1. Atliekant tyrimą apklausa buvo vykdoma Utenos mieste ir Utenos rajono kaimuose, apklausti 376 respondentai. Tyrimas yra reprezentatyvus, atliktas esant $95 \%$ tikimybei ir $5 \%$ paklaidai.

2. Nors didžioji miesto ir kaimo gyventojų dalis nereikalingus, bet tvarkingus ir tinkamus naudoti daiktus stengiasi kam nors atiduoti, tačiau dalijimosi stotelè „,Dalinkimès" nèra populiari nei tarp miesto, nei tarp kaimo gyventojų - šį tvarkymo būdą renkasi 3,1 \% (M) ir 8,0\% (K) respondentų.

3. Nustatyta, kad surenkant stambiagabarites ir pavojingąsias buityje susidarančias atliekas, susiduriama su dviem svarbiausiomis problemomis: kas trečias respondentas dali pavojingųjų atliekų išmeta kartu su buitinėmis atliekomis (dažniau kaime), $16 \%$ respondentų stambiagabarites atliekas palieka prie buitinių atliekų konteinerių (dažniau mieste). Tai gali sukelti ekologinių problemų tolesniuose buitinių atliekų tvarkymo etapuose, taip labai apsunkinamas atliekų tvarkytojų darbas, užgriozdinama aplinka.

4. Kaimo gyventojai aktyviau naudoja pavojingujų atliekų surinkimo būdą, kai jos surenkamos apvažiavimo būdu $-28,0 \%$. I didelių gabaritų aikšteles pavojingąsias atliekas labiau linkę pristatyti miesto gyventojai (19,8\%) nei kaimo gyventojai $(9,0 \%)$.

5. Didžioji dalis tiek miesto, tiek kaimo gyventojų pavojingujų atliekų tvarkymą Utenos rajono savivaldybejje vertina gerai (apie $48 \%(\mathrm{M})$ ir $68 \%(\mathrm{~K})$ ) arba vidutiniškai (apie $38 \%(\mathrm{M})$ ir $23 \%(\mathrm{~K})$ ).

6. Didelių gabaritų atliekų tvarkymas Utenos mieste ir rajone vertinamas dar palankiau nei pavojingujų atliekų tvarkymas: gerai šią paslaugą vertina apie $68 \%$ miesto gyventojų ir $77 \%$ kaimo gyventojų, o vidutiniškai - po $14 \%$ (M) ir $12 \%(\mathrm{~K})$ gyventojų.

\section{Literatūra}

Aplinkos apsaugos agentūra. (2020). Aplinkos apsaugos agentūros duomenys.

http://atliekos.gamta.lt/cms/index?rubricId=53f7a6c9-c7ee488b-8bc4-596bae493788

Kardelis, K. (2002). Moksliniu tyrimu metodologija ir metodai (2-asis pataisytas ir papildytas leidimas). Kaunas.

Kardelis, K. (2007). Moksliniu tyrimu metodologija ir technika. Lucilijus.

Lietuvos Respublikos aplinkos ministerija. (2018). Lietuvos Respublikos aplinkos ministro isakymas ,Dèl atlieku tvarkymo taisykliu patvirtinimo " (Nr. 217). Vilnius. https://e-seimas.lrs.lt/portal/legalAct/lt/TAD/TAIS. 84302? f wid=32wf9pme

Lietuvos Respublikos aplinkos ministerija. (2012). Lietuvos Respublikos aplinkos ministro isakymas ,Dèl minimaliu komunaliniu atlieku tvarkymo paslaugos kokybès reikalavimu patvirtinimo" (Nr. D1-857). Vilnius. https://e-seimas.lrs.lt/portal/legalAct/lt/TAD/TAIS.435756

Lietuvos Respublikos Seimas. (2021). Lietuvos Respublikos atlieku tvarkymo ịstatymas (Nr. VIII-787). Vilnius.

https://e-seimas.lrs.lt/portal/legalAct/lt/TAD/TAIS.5 9267/FSWYcQScor

Lietuvos Respublikos vyriausybè. (2002). Nutarimas „Dèl valstybinio atlieku tvarkymo 2014-2020 metu plano patvirtinimo" (Nr. 519). Vilnius.

https://e-seimas.lrs.lt/portal/legalAct/lt/TAD/ TAIS. 164386/asr

Oficialiosios statistikos portalas. (2019). https://osp.stat.gov.lt/lietuvos-statistikos-metrastis/lsm2019/aplinka-ir-energetika/aplinka

Valstybės kontrolè. (2018). Valstybinio audito ataskaita. Pavojingu atlieku tvarkymas.

https://am.lrv.lt/uploads/am/documents/files/atliekos/studijos-ataskaitos/VA-11_Ataskaita_Pavojingosios_atliekos.pdf 


\section{THE RESEARCH OF UTENA DISTRICT MUNICIPALITY RESIDENTS' HABITS OF MANAGING BULKY AND HOUSEHOLD HAZARDOUS WASTE}

\section{Jakštonienė, I. Pliopaitė Bataitienė, N. Rukštelienė}

\section{Summary}

The article analyzes the results from a survey of the residents of Utena district municipality, which aims to clarify the respondents' habits of managing bulky and household hazardous waste. According to the data of the Lithuanian Department of Statistics, on July 1, 2019 the population of Utena district municipality was 37,277 (25,406 in the city and 11,871 in the village). According to the same department data, in 2018 the average household in the district was 2.18 of a person, thus, there are about 17,100 households in Utena district municipality. During the research, an electronic questionnaire form was distributed to survey residents of Utena district municipality, and a paper questionnaire was additionally distributed in Antalge village, Vyžuonos and Tauragnai towns. There were 376 respondents interviewed, the survey is representative, performed with $95 \%$ of the probability and $5 \%$ of the error.

It was found that $95 \%$ of respondents believe that waste sorting helps to protect the nature and reduces the costs of waste management, while only a small number of respondents are skeptics on this issue. Unfortunately, it is challenging to put into practice, since even $21 \%$ of respondents say that they never use this kind of waste collection service, a third of respondents a part of the hazardous waste throw into municipal waste containers and a sixth of respondents simply leave bulky waste near the household waste containers.

Despite these problems, the respondents have a positive view on the work of UAB "Utenos komunalininkas" and other waste managers. The management of hazardous waste in Utena district municipality is evaluated as good by the majority of both urban $(\mathrm{U})$ and rural (R) residents (about $48 \%(\mathrm{U})$ and $68 \%(\mathrm{R})$ ) or on average (approx. 38\% (U) and 23\% (R)). Bulky waste management in Utena district municipality is rated even more favorable than hazardous waste management: this service is rated well by about $68 \%(\mathrm{U})$ and $77 \%(\mathrm{R})$, and on average by $14 \%(\mathrm{U})$ and $12 \%(\mathrm{R})$ of residents. Although the majority of urban and rural residents try to give away no longer needed but tidy items that are suitable for use, however, the sharing station "Dalinkimès" is not popular neither among urban nor rural residents $-3.1 \%$ (U) and $8.0 \%(\mathrm{R})$ of respondents choose this way of handling. Curbside collection of hazardous waste is more acceptable for residents of rural areas (28.0\%). Residents of urban areas (19.8\%) are more likely to deliver hazardous waste to specific large-scale sites than rural residents $(9.0 \%)$.

Keywords: Utena district municipality, bulky waste, hazardous waste, waste management. 